\title{
Relationships between Parfiya and Ancient Azerbaijan in the Context of Synthesis Materials
}

\author{
QA Pirquliyeva* \\ Department of History, Azerbaijan
}

*Corresponding author: QA Pirquliyeva, Department of History, BSU university, Azerbaijan.

Received Date: April 30, 2019

Published Date: May 23, 2019

\section{Opinion}

The famous linguist scientist notes in one of the works of I.Orsky that "peoples and tribes can have the same culture as they speak in different languages, and similarly, tribes with the same language or language can often be sharply different from each other due to their material culture "In this view, the Albanian Albanians, which existed at the same time with Parphyia, have many similarities with Atropatena - linguistic identity, cultural roots, and anthropological structure of people remain open to the discussion of world scholars. After the death of the great conqueror Alexander the Great, the political events in Eurasia are being studied on more numismatic materials.

In the smallest works of the III century and in few languages translated into the present day, the main idea is that the Empire was formed after the very intense conflicts and wars, first, in the Selevkies, and then on the eastern lands of Parfia. However, the "bridge" between the two geographical spaces was formed by the Caucasus and its local population States have been the same. The position in the settlement of this problem has been the same in the history of Russia and Soviet history for the last 30 years. The Caucasus was under Roman influence after the Selevkids, and then known historical events.

Numizmatical investigations were exactly synchronized with this ideological "line". It should be noted that in the XX century some Azerbaijani scholars engaged in the study of numismatic findings of antiquity have continued this trend. However, the material and cultural remains found in archaeological excavations, including coins and treasures, have denied this idea. The influence of GreekRoman culture in antiquity has been found in the foothills of the Caucasus Mountains, on the Black Sea coast - in the western part of modern Georgia. This can be summarized by the archaeological finds of colonies-city-states settled by the famous city of Vani or
Greek merchants. Archaeological investigations of such urban states do not prove that foreign foreign merchants are assimilated by local tribes. Similarly, archaeological investigations in recent North Azerbaijan in the last 70 years prove the absence of Seleucid - Roman influence.

The finds of Nyudi, Uzunboylar, Xinisli and other monuments in Shirvan, the cultural and cultural samples of Baku-Absheron, Shamakhi, Derbent. Selevki does not reflect at least a century of cultural influence of Roman antiquity until the third century of the III century BC. On the contrary, there are studies proving that Parfa belongs not only to the sphere of influence, but to the territory of the empire. "In some historical literature of the Ancient times, the Parthians are often referred to as" Midians ". The main reason for this is that Parfiya was originally created in the Mid-East region in the east", the author of the famous Soviet-Russian archaeologist VM Masson repeatedly relied on this idea. The local Turkish tribes played a special role in the coming of the Parthians to the power. It appears to be in honor of this nation that the title of hpkmdi was first adapted to the name of the people to which it belongs, and therefore, after the names of the principal titles of the last Parthian rulers, this was Arsak-Arshak; that same year, e. The 247 was included in the history as the New Arshakids calendar. In the honor of the Parn-party typhus, which is considered to be one of the foremost powers of the new state, Parfiya or power was named after the Arshakids-Ersak state in honor of Ersak.

In both European epics and ethnonym, both epones and ethnos are used. History of the new dynasty of the Turkic-speaking tribes, who did not come to power in the Median territory, continued until the Sassanid rule came to power. We emphasize the importance of those who live in the territory of the ruling elders, mainly Turkic language Specifically, it should be noted that the axis of the skull 
and skulls of the Sak-skif culture was not a novelty on the coins. That is, in the time of the last Ahamenians, the bronze and copper pulse, there are also images of man-human-ruler or fighter-inarms, both in the hands of the value units and in the hands of the attacker, as a fighter.

During the rule of the Parthians, just like in the ancient Ahamenians, this image continued in silver and gold, minted in coins, but on the rulers. One of the important peculiarities of the coins of this power is the image of the throne set by Arsak Arshak. This kind of simple, samples of the throne without examples can be watched by the coins of some kings of Turkic nations until the end of the XIX century. The last description of such coins in coins can be seen in the coins issued by the Turkish rulers Nadir Shah, Gajars in time.

Thus, Atropatena and Albanian states, at least simultaneously independent governance or nominal dependency on the arrival of the Parn tribes in the Midian territory. The borders of both states have changed, diminished and expanded from time to time. Nevertheless, the coins and coins found in the coins allowed them to locate the major cities of their capitals. From the 3rd century onwards, local silver drachmas were put into circulation in the territory of Azerbaijan Albania. The last pulse of these coins was the result of the last century's scientific studies. Until the middle of the first century. According to two major coins minted in modern North Azerbaijan in the late 1970s and 80s, these coins were included in the category of "varvar", "analogous" coins for the etalon concept adopted in the world of numismatics, and as the first historian of the local pulse, was adopted.

\section{Acknowledgement}

None.

\section{Conflict of interest}

No conflicts of interest. 